\title{
Perioperative pain management in the patient treated with opioids: Continuing Professional Development
}

\author{
Philippe Richebé, MD, PhD · Pierre Beaulieu, MD, PhD
}

Received: 19 August 2009/Accepted: 15 September 2009/Published online: 3 November 2009

(C) Canadian Anesthesiologists' Society 2009

\begin{abstract}
Purpose The objective of this continuing professional development module is to describe the perioperative anesthesia and pain management of patients taking opioids because of chronic pain or drug addiction.

Principal findings The number of patients under opioid treatment is increasing. Pain management is problematic in these patients, because regular opioid intake is associated with mechanisms of tolerance and dependence. More recently, opioid-induced hyperalgesia phenomena have been brought to light. As a rule, the usual opioid dose should be administered with the appropriate conversions, and additional requirements should be anticipated because of the surgical procedure. Local and regional anesthesia, and multimodal analgesia are indicated whenever possible. For the patient addicted to heroin or other opioids, the perioperative period is not a suitable time to initiate weaning.

Conclusion The physiological and pharmacological changes caused by chronic opioid intake must be
\end{abstract}

P. Richebé, MD, PhD ( $₫)$

Department of Anesthesiology and Pain Medicine, University of Washington Medical Center, Campus box 356540, 1959 NE Pacific Street, Seattle, WA 98195, USA

e-mail: prichebe@u.washington.edu

P. Beaulieu, MD, PhD

Department of Anesthesiology and Pharmacology, CHUMFaculté de Médecine, Université de Montréal, Montréal, QC, Canada understood in order to provide optimal pain management with respect to each individual and the type of procedure.

\section{Objectives of this continuing professional development module}

1. To be aware of the importance of chronic pain and become familiar with the indications for opioids;

2. To understand the pathophysiological mechanisms associated with chronic opioid consumption: tolerance, hyperalgesia, dependence, and other side effects;

3. To manage a patient during the perioperative period who is already treated with opioids; and

4. To understand and manage the case of a patient addicted to opioids.

The prevalence of chronic pain is increasing, with approximately one in five individuals being affected. ${ }^{1}$ Opioids are the most commonly taken drugs for the treatment of moderate to severe pain. At some point, patients suffering from chronic pain may have to undergo a surgical procedure related to their condition, such as prosthetic replacement because of arthritis, or a procedure unrelated to the initial chronic lesion, such as cardiac or trauma surgery. Optimal perioperative management is directed toward preventing inadequate pain relief due to an inadequate dosage of opioids. The objective of this review is to understand the physiopathological mechanisms associated with chronic opioid consumption (tolerance, dependence, and hyperalgesia) and to provide the best possible pain management to these patients during the perioperative period. $^{2,3}$ Finally, the special case of the opioid-addicted patient will de discussed. 


\section{The chronic pain patient}

Etiology and epidemiology of chronic pain

Chronic pain can be of non-cancerous or cancerous origin. A classification and examples are provided in Table 1. According to data collected in 15 European countries and Israel during a telephone survey of 46,394 participants, ${ }^{4}$ the prevalence of chronic pain varies depending on the country; however, moderate to severe pain was present in an average of $19 \%$ of adults. In Canada, according to phone interviews of 2,012 adult patients older than 18 years of age, ${ }^{5}$ non-cancerous chronic pain was reported in $29 \%$ of the population, with a greater prevalence in women and the elderly. Pain had been present for an average of 10.7 years with a mean intensity of 6.3 on a scale of $1-10$. However, a strong opioid was prescribed in fewer than $10 \%$ of cases.

Pharmacological treatment of chronic pain

Chronic pain has several origins, the most frequent and feared being neuropathic, since it is more difficult to treat. ${ }^{6}$ Overall, opioids appear to be second- or third-line treatment drugs, even first-line in some cases. However, the number of chronic pain patients taking opioids is difficult to assess.

\section{Different opioid drugs}

Many opioid drugs are available for chronic pain patients, such as morphine, codeine, hydrocodone (not available in Canada), hydromorphone, oxycodone, buprenorphine (not available in Canada), fentanyl, or methadone. Tramadol is also used, although it is not only an opioid agonist but also an adrenaline and serotonine reuptake inhibitor at the spinal level. Oral opioids include controlled release preparations. In addition, subcutaneous, transdermal, and epidural routes are also used. The chronic intake of opioids has an impact on postoperative pain management. ${ }^{7-9}$ Thus, according to two studies, patients already taking opioids required three to four times as much opioids in the postoperative period than patients not taking opioids before surgery.

\section{The consequences of chronic opioid consumption}

Tolerance, dependence, and hypersensitivity

Before addressing tolerance, dependence, and hypersensitivity as consequences of chronic opioid consumption, we briefly define these terms. Tolerance to a drug can simply be defined as the need to increase dosage to obtain a similar analgesic effect. Physical dependence can be defined as discernible withdrawal symptoms when the drug is suddenly interrupted, when the dosage is reduced too quickly, or when antagonists are administered.

Hyperalgesia is said to occur when a mechanical stimulation that is not very painful initially becomes more painful after exposure to a pharmacological agent or a lesion. Allodynia refers to a mechanical stimulation that is not painful initially but becomes painful after exposure to the same pharmacological agent or lesion. Hyperalgesia and allodynia are two types of hypersensitivity.

There are various direct quantitative assessment methods that can be used in the perioperative period. The von Frey filaments ${ }^{10}$ and algometry ${ }^{10}$ are the most commonly used.

Assessment can also be made indirectly by noting the pain scores on a visual or numerical scale while the patient is at rest, under exertion, or under mechanical stimulation. The patient's consumption of postoperative analgesics or need for rescue analgesics outside of the postoperative analgesia protocol can also be assessed in this manner; however, the evaluation then remains inaccurate. There is also a definite interindividual variability in postoperative hypersensitivity due to factors that remain largely unknown, e.g., genetics, influence of age and gender, duration and intensity of preoperative pain and hyperalgesia, preoperative analgesic consumption, type of surgery, dosage of intraoperative opioids, and so on.

\section{Opioid-induced hyperalgesia}

When high doses of opioids are administered or when these drugs are administered for a long time, it seems that, among other phenomena, up-regulation of pronociceptive systems occurs, and this eventually leads to a change in sensitivity to pain called opioid-induced hyperalgesia

Table 1 Etiology of chronic pain

\begin{tabular}{llll}
\hline & Origin & Sub-type & Examples \\
\hline $\begin{array}{l}\text { Cancerous pain } \\
\text { Non-cancerous pain }\end{array}$ & Neuropathic & Peripheral & $\begin{array}{c}\text { Metastatic cancer } \\
\text { Complex regional pain syndrome I and II, trigeminal } \\
\text { neuralgia, post-herpetic neuralgia, phantom pain } \\
\text { Multiple sclerosis, spinal cord injuries, following a stroke }\end{array}$ \\
& Neuropathic & Central & Arthritis, intervertebral disk degenerative disease, fibromyalgia \\
& Nociceptive & Somatic & Chronic pancreatitis, irritable bowel syndrome \\
\hline
\end{tabular}


(OIH). This difference in sensitivity, be it allodynia or hyperalgesia, can be assessed and revealed by applying various thermal or mechanical stimuli. ${ }^{11,12}$ Several studies support this OIH hypothesis. ${ }^{13}$

The cellular mechanisms inducing $\mathrm{OIH}$ are still poorly understood and could be multiple. Increased pain sensitivity in the perioperative period associated with slow-release opioids or high doses of opioids given acutely have been well documented in the clinical setting. ${ }^{10,13,14}$ In patients under slow-release opioid treatment, this leads to a lowering of the pain threshold, more severe pain at incision, higher and more prolonged postoperative pain, an increase in postoperative opioid consumption, and an increase in postoperative discomfort. ${ }^{10}$ The role of OIH in the development of tolerance is controversial. Nevertheless, it seems clear that during opioid withdrawal, OIH could develop and contribute to exacerbation of pain. ${ }^{7}$

\section{Polypharmacy}

Chronic pain is frequently associated with anxiety, depression, and polymedication (opioids, non-steroidal antiinflammatory drugs or NSAIDs, cyclooxygenase-2 (COX-2) inhibitors, anticonvulsants, antidepressants, muscle relaxants, $\alpha$-adrenergic agonists, benzodiazepines). In addition, patients have a tendency to underestimate the doses they take, which increases the risk of withdrawal syndrome and increased intraoperative and postoperative pain. ${ }^{4}$ However, there may be incomplete cross-tolerance between opioids, and this is an argument in favor of opioid rotation, which, in some cases, could help in perioperative pain management.

\section{Other side effects}

Side effects, such as nausea, vomiting, sedation, pruritus, constipation, and respiratory depression are dose-dependent. There is an interindividual variability as well as a certain variation between opioids. In the patient taking opioids chronically, there is a tolerance to all side effects except constipation, and endocrine, gonadal and immune suppression. Moreover, chronic opioid consumption is thought to induce some effects that are still poorly explained, e.g., delay in scar formation, increased complication rate, and increased risk of chronic pain.

\section{Perioperative management (Table 2)}

Preoperative period

According to the most recent recommendations of the International Association for the Study of Pain (IASP
Table 2 Perioperative management

\begin{tabular}{|c|c|}
\hline \multicolumn{2}{|l|}{ Preoperative period } \\
\hline Opioids & $\begin{array}{l}\text { If needed, convert between } \\
\text { administration route and various } \\
\text { opioids; continue same dosage as } \\
\text { before surgery; avoid agonists- } \\
\text { antagonists; remove fentanyl patch } \\
\text { and provide equivalent as parenteral } \\
\text { opioid. }\end{array}$ \\
\hline \multirow[t]{3}{*}{ Multimodal analgesia } & Acetaminophen \\
\hline & NSAIDs \\
\hline & Gabapentin, pregabaline \\
\hline \multicolumn{2}{|l|}{$\begin{array}{l}\text { Locoregional anesthesia } \\
\text { and analgesia }\end{array}$} \\
\hline \multicolumn{2}{|l|}{ Intraoperative period } \\
\hline Opioids & At the anesthesiologist's discretion \\
\hline \multicolumn{2}{|c|}{ Regional anesthesia and analgesia } \\
\hline $\begin{array}{l}\text { Local anesthesia at the } \\
\text { wound }\end{array}$ & With or without catheter \\
\hline Adjuvants & Ketamine, clonidine \\
\hline Inhalation risk & Increased \\
\hline \multicolumn{2}{|l|}{ Postoperative period } \\
\hline Intrathecal route & $\begin{array}{l}\text { Intrathecal opioids more efficaceous } \\
\text { than intravenous opioids }\end{array}$ \\
\hline \multirow[t]{2}{*}{ Epidural analgesia } & Local anesthetics and opioids \\
\hline & Can be patient-controlled \\
\hline Opioid pump (if in place) & Continue baseline dose \\
\hline \multirow{2}{*}{$\begin{array}{l}\text { Intravenous patient- } \\
\text { controlled analgesia } \\
\text { (PCA) }\end{array}$} & $\begin{array}{l}\text { Provide the basic requirements by } \\
\text { continuous infusion }\end{array}$ \\
\hline & $\begin{array}{l}\text { Anticipate increased requirements of } \\
30-50 \%\end{array}$ \\
\hline \multirow[t]{2}{*}{ Multimodal analgesia } & Acetaminophen \\
\hline & NSAIDs \\
\hline Adjuvants & Ketamine, clonidine, gabapentin \\
\hline
\end{tabular}

NSAIDs Non-steriodal anti-inflammatory drugs

2005), patients taking opioids to control chronic pain, because of an addiction, or as part of an illegal use should not be intentionally weaned off this type of drugs during an acute painful medical or surgical episode. Therefore, in the preoperative period, care providers must be able to identify patients who regularly consume opioids, for whatever reason, as well as recognize those who suffer from chronic pain and the frequently associated psychological conditions, such as depression, anxiety, and personality disorders. The main principle to respect with these high-risk patients is not to induce weaning or $\mathrm{OIH}$ in the perioperative period.

The approach must be multidisciplinary, and the following issues should be addressed before the surgery: determining the opioids that will be used (type, frequency, dosage), choosing the postoperative analgesic options (local or regional anesthesia, multimodal analgesia), and establishing patient follow-up and management with respect to the patient's pain, behavioural disorder (mainly anxiety and 
depression), or signs of opioid withdrawal should a transient under-dosage of opioid analgesics occur. Among the psychological factors affecting the outcome of such patients after surgery, it seems that depression and anxiety before surgery are indicators of a higher risk of experiencing a high level of postoperative pain, a slower rehabilitation, and more postoperative complaints.

Recently, various models of pain self-management have been put forward to help these patients become more active in the management of their pain. ${ }^{15}$ This type of active approach creates a decision-sharing paradigm between the patient and the healthcare team, which helps to optimize the patient's level of investment in his/her treatment and to improve the management of pain. Before anesthesia, the total daily consumption of the patient taking slow-release opioids must be assessed. Cross reference tables are available and should be used to determine the patient's baseline opioid level (Table 3). The assessment must take into account the following elements: route of administration, pharmacokinetic parameters, and absorption, e.g., per os morphine is less rapidly absorbed than controlled release methadone or oxycodone. As a rule, transcutaneous fentanyl or its equivalent should be continued postoperatively as so-called basal analgesia. However, fentanyl absorption can be altered unpredictably depending on type of surgery, amount of fluids administered intraoperatively, and skin temperature at the end of the procedure. Thus, it is preferable in most of these cases to remove the fentanyl patch and to administer an equipotent dose of morphine as a substitute. Indeed, some studies have reported the risks induced by hypothermia ${ }^{16}$ or rewarming ${ }^{17}$ on the absorption kinetics of fentanyl.

The usual opioid dose or its equivalent must be given on the morning of surgery or at induction. If the patient has an implanted intrathecal or epidural opioid administration system, the same dosage should be maintained throughout the surgery. For many years, the principle of preoperative opioid rotation has been put forward in order to limit the risk of withdrawal and $\mathrm{OIH}$ and thus reduce opioid doses. However, it is imperative to avoid agonists-antagonists, such as nalbuphine, buprenorphine, pentazocine, and so on, which may induce sudden withdrawal or OIH. Rotation to

Table 3 Equipotent opioid analgesic doses (mg), according to Joly et al. ${ }^{10}$

\begin{tabular}{lll}
\hline Drug & Oral dose & Parenteral dose \\
\hline Morphine & 15 & 5 \\
Hydromorphone & 4 & 1 \\
Fentanyl & - & 0.1 \\
Methadone (acute) & 0.8 & 1 \\
Oxycodone & 10 & - \\
\hline
\end{tabular}

another $\mu$-agonist opioid generally allows for a reduction in the total opioid equivalent doses because of an incomplete cross tolerance between opioids. However, this preoperative rotation appears to be difficult to achieve in practice, since the transfer from one opioid to the other should be very progressively titrated. ${ }^{18}$ In addition, we do not know whether this rotation may have an impact in terms of postoperative pain, tolerance, and $\mathrm{OIH}$. Finally, some authors have suggested a test dose of fentanyl ${ }^{19}$ preoperatively to estimate the response of such patients to intraoperative opioids. This test remains difficult to apply in clinical practice.

Multimodal analgesia is recommended 1 or $2 \mathrm{~h}$ before surgery, including the administration of acetaminophen and COX-2 selective or classical NSAIDs per os. Most nonopioid drugs have not been specifically tested in chronic pain patients but have been associated with a decrease in postoperative morphine consumption in non opioid-addicted subjects. Finally, new therapies aimed at limiting postoperative pain sensitization and preventing pain from becoming chronic may be useful as premedication. Consequently, gabapentine $600-1200 \mathrm{mg}$ and pregabaline have been suggested as adjuvants to perioperative analgesia. ${ }^{20}$ Although these drugs have not been tested in the chronic opioid consumer, they could prove useful in these patients. Regional anesthesia and analgesia will control pain at the surgical site but will by no means limit the symptoms of acute opioid withdrawal or its systemic consequences.

\section{Intraoperative period}

While some authors have provided evidence for acute tolerance to specific opioids used intraoperatively in human subjects and animals, ${ }^{11}$ nothing has yet been reported in patients who are chronic opioid consumers. Similarly, although $\mathrm{OIH}$ induced by high doses of intraoperative opioids has been reported with the majority of opioids used in clinical practice (fentanyl, remifentanil, sufentanil, alfentanil), ${ }^{10,14}$ there are no data to support the choice of an intraoperative opioid over another in patients chronically treated with opioids or to predict the level of intraoperative tolerance. Therefore, the selection of an opioid remains at the discretion of the anesthesiologis responsible for the patient, and the doses should be titrated following the usual method. Local and regional anesthesia should be preferred to limit intraoperative opioid doses either by inserting catheters or by long-acting single shot injections. ${ }^{21}$ Nevertheless, we should keep in mind that analgesia will be restricted to the surgical site and will by no means limit the systemic effects of opioid withdrawal, which will then have to be prevented.

Ketamine, an $n$-methyl-D-aspartate (NMDA) receptor antagonist, showed its efficiency to reduce hyperalgesia 
Table 4 Example of ketamine dosage

\begin{tabular}{llll}
\hline Surgery type & Induction & Maintenance \\
\cline { 3 - 4 } & & Infusion & Bolus \\
\hline Very painful & $0.5 \mathrm{mg} \cdot \mathrm{kg}^{-1}$ & $0.5 \mathrm{mg} \cdot \mathrm{kg}^{-1} \cdot \mathrm{h}^{-1}$ & $0.25 \mathrm{mg} \cdot \mathrm{kg}^{-1}$ every $30 \mathrm{~min}$ \\
Moderately painful & $0.25 \mathrm{mg} \cdot \mathrm{kg}^{-1}$ & $0.25 \mathrm{mg} \cdot \mathrm{kg}^{-1} \cdot \mathrm{h}^{-1}$ & $0.125 \mathrm{mg} \cdot \mathrm{kg}^{-1}$ every $30 \mathrm{~min}$ \\
\hline
\end{tabular}

and postoperative morphine consumption in animal models or non-tolerant patients. ${ }^{12}$ When administered perioperatively, ketamine decreases pericicatricial hyperalgesia. ${ }^{10}$ Several recent meta-analyses report that the beneficial effect of ketamine on the intensity of postoperative pain and on analgesic consumption exceeds five elimination half-lives of the compound. ${ }^{22,23}$ The recommended doses of ketamine are presented in Table 4. Despite the absence of data regarding the tolerant patient, it seems logical to offer ketamine as adjuvant therapy to reduce the amount of opioids used perioperatively and to try to block OIH and postoperative tolerance. ${ }^{7}$ A recent study examined tolerant patients in the recovery room and revealed the beneficial effect of a simple postoperative ketamine bolus to limit acute tolerance to postoperative morphine. ${ }^{24}$ Dextromethorphan has similar properties as ketamine, but has been much less studied. Besides ketamine, clonidine and dexmedetomidine have been studied. Clonidine decreases the secondary hyperalgesia area and postoperative morphine requirements. ${ }^{12}$ However, intrathecal clonidine has marked hemodynamic side effects. Intravenous dexmedetomidine appears to blunt withdrawal symptoms in patients who chronically consume opioids. ${ }^{25}$

The type of surgery must be taken into account. A few authors suggest that the opioid doses offered to the patient should be decreased after a surgical procedure associated with substantial pain reduction, because of the risk of respiratory depression. ${ }^{3,9}$ Others suggest titrating opioids to allow for the return of spontaneous breathing at a frequency of 12-14 breaths $\min ^{-1}$. ${ }^{3}$ Lastly, it seems that patients who chronically consume opioids must be considered as being at a higher risk of pulmonary aspiration because of a delay in gastric emptying. Therefore, the anesthetic must be planned and managed so as to limit this risk.

\section{Postoperative period}

An intrathecal or epidural combination of low doses of opioids and local anesthetic agents is commonly used in most institutions. In fact, there might be a down-regulation of central opioid receptors when opioids are used in an intrathecal or epidural route, while the analgesic effect of the local anesthetic is not affected by this opioid tolerance. Neuraxial regional anesthesia decreases pericicatricial allodynia around the surgical incision and may limit development of chronic postoperative pain.
As an example, epidural analgesia may be provided by bupivacaine at a low concentration $\left(0.625 \mathrm{mg} \cdot \mathrm{mL}^{-1}\right.$ or $0.0625 \%$ ), rather than ropivacaine, chiefly for cost considerations. The addition of opioids, e.g., fentanyl $2 \mu \mathrm{g} \cdot \mathrm{mL}^{-1}$ or sufentanil $0.5-1.0 \mu \mathrm{g} \cdot \mathrm{mL}^{-1}$ to the local anesthetic solution is indicated in most circumstances. The continuous epidural infusion rate can vary from 5 to $10 \mathrm{~mL} \cdot \mathrm{h}^{-1}$ and patient-controlled boluses of $2-5 \mathrm{~mL}$ are given with a refractory period of $8-10 \mathrm{~min}^{3}$

If the patient has an implanted opioid pump pre- and intra-operatively, the same dosage should be continued to provide a so-called "basal analgesia" to the patient. For opioids, the neuraxial route seems to be more efficaceous than the intravenous route. The doses should also be adjusted preoperative doses, considering equipotent values. ${ }^{9}$ However, the above-described risks of OIH are as present with intravenous as well as intrathecal administration. ${ }^{26}$

If the patient does not benefit from local or regional anesthesia, a transition to patient-controlled analgesia (PCA) based on the following example should be considered. If the patient takes morphine $60 \mathrm{mg}$ per os daily preoperatively, this corresponds to $20 \mathrm{mg}$ intravenous morphine per day, i.e., a background infusion of morphine at $0.8 \mathrm{mg} \cdot \mathrm{h}^{-1}$ to which intermittent boluses $1-2 \mathrm{mg}$ are added every 6-10 min if needed. If the requested doses/ received doses ratio $>3$, the background infusion should be increased by $20 \%$ and the patient should be reassessed. Then, the amount administered should be tapered to aim, at least initially, for return to the patient's preoperative doses.

Postoperatively, there is often a $30-50 \%$ increase in opioid requirements compared with preoperative equivalents. However, this is only true when surgery involves a strong pain component! Patients for whom surgery is intented to decrease preoperative pain will experience reduced requirements compared with the preoperative period and will need fewer opioids.

There are many advantages of morphine PCA in such patients: easy and immediate use; stable plasma levels; pain relief with a lower total consumption; fewer confrontations between patient and the healthcare team; as well as avoiding anxiety and acute withdrawal episodes. However, sometimes the adaptation can initially prove difficult, and there is a risk of pseudo-addiction behaviour. For this reason, morphine PCA was initially controversial for these patients; nevertheless, it is now well accepted. ${ }^{27}$ Furthermore, the 
addition of ketamine, clonidine, acetaminophen, NSAIDs, gabapentin and/or regional anesthesia should be considered.

\section{The special case of the opioid-addicted patient}

Heroine remains the main substance consumed by drug addicts, although cocaine is becoming increasingly popular. ${ }^{3}$ Today, approximately one in three heroin addicts injects the drug, but the majority of toxicomaniacs prefer smoking it or taking it via the intranasal route. In addition, morphine derivatives, such as oxycodone, hydromorphone, and methadone, have received special attention. For instance, controlled release caplets of oxycodone can be crushed, ground to powder, and then injected intravenously or sniffed. Methadone caplets are also targeted. Besides, abuse of other products is common, and the consumption of these substances increases proportionally to that of heroine. Such patients can present organ lesions, infectious diseases, such as HIV, tuberculosis, and hepatitis, as well as psychological problems. In addition, the development of tolerance and dependence together with the appearance of a withdrawal syndrome when the drug intake is interrupted further complicate the picture.

For the addicted patient, the institutional substitution of heroine by methadone is also possible in specialized centres. $^{28}$ As is the case with other patients under chronic opioid therapy, these individuals taking heroine or methadone show a hyperalgesic state. Such patients may need surgery for a procedure that is related to their condition (abscess drainage, valve replacement) or because of a common condition (appendectomy, fracture, osteosynthesis, and so on). Drug addicts should receive a baseline opioid dosage considering the last opioid used and, in the case of heroine, its purity. The onset of withdrawal syndrome can be $6-18 \mathrm{~h}$ after the last administration of morphine and heroine, and $24-48 \mathrm{~h}$ after methadone. ${ }^{3}$ It is worth mentioning that an ex-addict could experience a renewed dependence following the preoperative use of morphinic agents.

In any case, care providers must reassure the patient and explain how his/her pain will be managed before the operation. A precise healthcare contract between the healthcare team and the drug-addicted patient should be considered for this purpose; this will help to gain the patient's trust. The message to the healthcare team is clear; i.e., opioid treatment should not be restricted in those patients; rather, any pain should be treated aggressively while keeping in mind the pharmacological and psychological differences present in such patients ("faking" patient). Care providers should also be careful not to emit any unsuitable judgment regarding the fact that the patient is an addict. Moreover, the perioperative period is not the best time to initiate weaning or to attempt rehabilitation in such patients. This can be considered by the addictology team after hospital discharge. Finally, the perioperative pain management in the patient specifically treated with methadone has been reviewed recently. ${ }^{28}$ When a local or regional anesthesia technique can be performed and is suitable for the type of surgery and the patient, it should be preferred.

\section{Case scenario}

A 28-year-old man presents to the emergency department with an acute abdomen. Acute appendicitis is diagnosed and the surgeon contacts you to perform an appendectomy, which is scheduled in $2 \mathrm{~h}$. The patient is in pain (7 out of 10 on a verbal numerical scale) and asks for relief. When questioned, the patient admits to heroine addiction for several months, but there has never been a medical follow up. Besides, the patient is in "good health" with no known medical history or allergies.

\section{Instructions for completing the CPD module}

(1) Read the references indicated in bold.

(2) Visit the Canadian Journal of Anesthesia website: http://www.springer.com/medicine/anesthesiology/jo urnal/12630 Click "CDP online" and select the current module, Perioperative pain management in the patient treated with opioids.

(3) Answer the multiple choice questions regarding the case scenario.

(4) When you have entered all of your answers, you will gain access to experts' explanations for all the possible choices.

(5) Participants may claim up to $4 \mathrm{~h}$ of CPD, for a total of eight credits under Section 3 of the CPD program of the Royal College of Physicians and Surgeons of Canada.

\section{Prise en charge de la douleur périopératoire chez le patient sous opioïdes}

\author{
Résumé \\ Objectif $\mathrm{Ce}$ module de développement professionnel \\ continu vise à décrire la prise en charge de l'anesthésie et \\ de la douleur dans la période périopératoire chez le patient
}


prenant des opioïdes à cause de douleurs chroniques ou en raison d'une toxicomanie.

Constatations principales Le nombre de patients sous opioïdes est en augmentation. La prise en charge de la douleur pose un problème chez ces patients. En effet, la prise régulière d'opioïdes est associée à des mécanismes de tolérance et de dépendance. Plus récemment, on a découvert des phénomènes d'hyperalgésie induite par ces mêmes opioïdes. En général, on doit administrer la dose habituelle d'opioïdes en effectuant les conversions appropriées et en plus, prévoir des besoins accrus liés à la chirurgie. L'anesthésie locorégionale et l'analgésie multimodale doivent être privilégiées le plus possible. Pour le patient toxicomane à l'héroïne ou à d'autres opioüdes, la période périopératoire n'est pas propice à l'initiation d'un sevrage. Conclusion Les changements physiologiques et pharmacologiques produits par une prise chronique d'opioïles doivent être compris afin d'offrir une gestion optimale de la douleur en fonction de chaque individu et du type d'intervention.

\section{Objectifs de ce module de développement professionnel continu}

1. Réaliser l'importance de la douleur chronique et connaître les indications des opioïdes;

2. Comprendre les mécanismes physiopathologiques liés à la consommation chronique d'opioïdes : tolérance, hyperalgésie, dépendance et autres effets secondaires;

3. Dans la période périopératoire, être en mesure de prendre en charge un patient déjà sous opioïdes;

4. Comprendre et gérer le cas du patient toxicomane dépendant des opiö̈des.

La douleur chronique est de plus en plus fréquente dans la population et elle touche environ une personne sur cinq. ${ }^{1}$ Les opiö̈des sont les médicaments les plus consommés dans le traitement de la douleur modérée à sévère. Ces patients peuvent avoir à subir une intervention chirurgicale en lien avec leur pathologie, par exemple un remplacement prothétique pour arthrose, ou à cause d'une nécessité sans rapport avec l'atteinte chronique initiale, par exemple une chirurgie cardiaque ou traumatique. La prise en charge optimale dans la période périopératoire vise à prévenir un soulagement inadéquat de la douleur dû à une prescription trop faible d'opioïdes. L'objectif de cette synthèse est de comprendre les mécanismes physiopathologiques liés à la consommation chronique d'opioïdes (tolérance, dépendance et hyperalgésie) et de gérer au mieux la prise en charge de la douleur chez ces patients dans la période périopératoire. ${ }^{2,3}$ Finalement, le cas particulier du patient toxicomane dépendant des opioïdes est abordé.

\section{Le patient atteint de douleurs chroniques}

Étiologie et épidémiologie de la douleur chronique

La douleur chronique peut être d'origine non cancéreuse ou cancéreuse. Une classification et des exemples sont donnés au Tableau 1. D'après des données recueillies dans 15 pays européens et Israël lors d'un sondage téléphonique réalisé auprès de 46394 participants, ${ }^{4}$ la prévalence était variable selon les pays, mais en moyenne des douleurs modérées à sévères étaient présentes chez $19 \%$ de la population adulte. Au Canada, d'après des entrevues téléphoniques auprès de 2 012 patients adultes de plus de 18 ans, ${ }^{5}$ des douleurs chroniques non cancéreuses ont été rapportées chez $29 \%$ de la population, et dans une plus grande proportion chez les femmes et les sujets âgés. Ces douleurs duraient en moyenne depuis 10,7 années, avec une intensité moyenne de 6,3 (sur une échelle de 1 à 10). Toutefois, un opioïde fort n'était prescrit que dans moins de $10 \%$ des cas.

Traitement pharmacologique de la douleur chronique

La douleur chronique a plusieurs origines mais la plus fréquente et la plus redoutée car plus difficile à traiter est la douleur neuropathique. ${ }^{6}$ Dans l'ensemble, il apparaît que les opioïdes sont des médicaments de deuxième ou troisième ligne, voire première ligne dans certains cas.

Tableau 1 Étiologie de la douleur chronique

\begin{tabular}{|c|c|c|c|}
\hline & Origine & Sous-type & Exemples \\
\hline Douleur cancéreuse & & & Cancer métastatique \\
\hline \multirow[t]{4}{*}{ Douleur non cancéreuse } & Neuropathique & Périphérique & $\begin{array}{l}\text { Syndrome douloureux régional complexe I et II, névralgie du trijumeau, } \\
\text { névralgie post-herpétique, douleurs du membre fantôme }\end{array}$ \\
\hline & Neuropathique & Centrale & $\begin{array}{l}\text { Sclérose en plaques, lésions de la moelle épinière, } \\
\text { suite à un accident vasculaire cérébral }\end{array}$ \\
\hline & Nociceptive & Somatique & Arthrose, maladie dégénérative du disque intervertébral, fibromyalgie \\
\hline & Nociceptive & Viscérale & Pancréatite chronique, syndrome du côlon irritable \\
\hline
\end{tabular}


Néanmoins, le nombre de patients avec douleurs chroniques prenant des opioïdes est difficile à chiffrer.

\section{Différents traitements opioïdes}

Différents opioïdes sont utilisés aujourd'hui par les patients avec douleurs chroniques : morphine, codéine, hydrocodone (non disponible au Canada), hydromorphone, oxycodone, buprénorphine (non disponible au Canada), fentanyl, méthadone. Le tramadol est aussi utilisé, bien qu'il ne soit pas simplement un agoniste opiö̈de mais également un inhibiteur de la recapture d'adrénaline et de sérotonine au niveau spinal. Pour la voie orale, il existe des préparations à libération prolongée. De plus, les voies sous-cutanée, transdermique et péridurale sont utilisées. La prise d'opioïdes de manière chronique a un impact sur la gestion de la douleur postopératoire. ${ }^{7-9}$ Ainsi, selon deux études, les patients déjà sous opioïdes avaient, en période postopératoire, des besoins augmentés de 3 à 4 fois comparés aux patients ne prenant pas d'opioïdes avant la chirurgie.

\section{Conséquences de la consommation chronique d'opiö̈des}

\section{Tolérance, dépendance et hypersensibilité}

Avant d'aborder tolérance, dépendance et hypersensibilité comme des conséquences d'une consommation chronique d'opioïdes, il semble opportun de définir ces termes succinctement. La tolérance à un médicament peut se définir simplement comme la nécessité d'augmenter les doses pour obtenir un même effet analgésique. La dépendance physique se manifeste par des symptômes de sevrage lors de l'arrêt brusque du médicament, d'une baisse trop rapide de son dosage, ou d'une administration d'antagonistes. L'hyperalgésie est définie par une stimulation mécanique initialement peu douloureuse qui devient plus douloureuse après exposition à un agent pharmacologique ou une lésion. L'allodynie est une stimulation mécanique non douloureuse initialement et qui devient douloureuse après exposition au même agent pharmacologique ou lésion. L'hyperalgésie et l'allodynie sont deux formes d'hypersensibilité.

Il existe diverses méthodes d'évaluation quantitative directes et utilisables en période périopératoire. Les plus utilisées sont les filaments de von Frey, ${ }^{10}$ et l'algométrie. ${ }^{10}$

Cette évaluation peut aussi se faire de façon indirecte mais reste alors imprécise, en notant les scores de douleurs au repos, à l'effort ou à la stimulation mécanique sur une échelle visuelle ou numérique, la consommation d'analgésiques postopératoires, ou le recours à des analgésiques de secours hors protocole d'analgésie postopératoire. Il existe une variabilité interindividuelle certaine des hypersensibilités postopératoires, due à des facteurs encore mal connus : génétique, influence de l'âge et du sexe, durée et intensité de douleur et hyperalgésie préopératoires, consommation d'antalgiques préopératoire, type de chirurgie, doses d'opioïdes peropératoires...

\section{Hyperalgésie induite par les opioïdes}

Lors de l'administration de fortes doses d'opioïdes, ou lors d'administrations prolongées de ces mêmes médicaments, il se développerait, entre autres phénomènes, une régulation à la hausse (« up-regulation ») des systèmes pronociceptifs qui aboutirait à une modification de sensibilité à la douleur que l'on nomme hyperalgésie induite par les opioüdes (« OpioidInduced-Hyperalgesia » ou OIH). Cette différence de sensibilité, ou allodynie ou hyperalgésie, est évaluée et mise en évidence grâce à divers stimuli thermiques ou mécaniques. ${ }^{11,12}$ De nombreuses études appuient cette hypothèse d'OIH. ${ }^{13}$

Les mécanismes cellulaires produisant l'OIH sont encore mal connus et pourraient être multiples. En clinique, ces phénomènes d'exacerbation de la sensibilité à la douleur par les opioïdes au long cours ou par les fortes doses aiguës d'opiö̈des ont été largement documentés en période périopératoire. ${ }^{10,13,14} \mathrm{Ceci}$ aboutit chez les patients sous traitement opioïde au long cours à un abaissement du seuil de douleur, une douleur plus sévère à l'incision, des douleurs postopératoires plus fortes et plus prolongées, une élévation de la consommation d'opioïdes postopératoires, et une augmentation de l'inconfort postopératoire. ${ }^{10} \mathrm{Le}$ rôle de l'OIH dans le développement d'une tolérance est encore sujet à controverse. Cependant, il semble clair que lors d'un sevrage en opioïdes, l'OIH apparaitrait et contribuerait à une exacerbation de la douleur. ${ }^{7}$

\section{Polypharmacie}

À la douleur chronique s'associent souvent anxiété, dépression et polymédication (opioïdes, anti-inflammatoires non-stéroïdiens, inhibiteurs de la cyclo-oxygénase de type 2 , anticonvulsivants, antidépresseurs, relaxants musculaires, agonistes $\alpha$-adrénergiques, benzodiazépines). De plus, les patients ont aussi tendance à sous-estimer les doses qu'ils ingurgitent, ce qui augmente le risque d'être exposé à un syndrome de sevrage et à des douleurs per- et postopératoires majorées. ${ }^{4}$ Cependant, le fait qu'il existerait une tolérance croisée incomplète entre les opioïdes soutiendrait le principe de rotation des opioïdes et pourrait dans certains cas aider à gérer la douleur en période périopératoire.

Autres effets secondaires

Les effets secondaires tels que les nausées, vomissements, sédation, prurit, constipation et dépression respiratoire sont 
dépendants de la dose. Il existe une variabilité inter-individuelle et aussi une certaine variation entre les opioïdes. Chez le patient consommateur chronique d'opioïdes, il existe une tolérance à tous les effets indésirables, sauf à la constipation et à la suppression endocrine, gonadique et immunitaire. De plus, la consommation chronique d'opioïdes induirait certains effets encore mal expliqués : retard de cicatrisation, augmentation du taux de complications, risque accru de douleurs chroniques.

\section{Prise en charge périopératoire (Tableau 2)}

Période préopératoire

Selon les recommandations les plus récentes de l'International Association for the Study of Pain (IASP 2005), les patients prenant des opioïdes par prescription contre la douleur, comme thérapie d'une addiction ou comme usage illégal ne doivent pas être délibérément sevrés de ces

Tableau 2 Prise en charge périopératoire

Période préopératoire Opioïdes

Analgésie multimodale

Anesthésie et analgésie locorégionale

Période peropératoire

Opioïdes

Anesthésie et analgésie locorégionale

Anesthésie locale au niveau Avec ou sans cathéter de la plaie

Adjuvants

Risque d'inhalation

Période postopératoire

Voie intrathécale

Analgésie péridurale

Pompe à opioïdes (si installée)

Analgésie intraveineuse contrôlée par le patient (ACP)

Analgésie multimodale

Adjuvants
Si nécessaire, faire la conversion entre voie d'administration et différents opioïdes; Continuer même posologie qu'avant la chirurgie; Éviter les agonistesantagonistes; Enlever le timbre de fentanyl et fournir l'équivalent en opioïde parentéral.

Acétaminophène; Antiinflammatoires non stéroïdiens Gabapentine, prégabaline

\section{ale}

À la discrétion de l'anesthésiologiste

Kétamine, clonidine

Augmenté

Opioïdes intrathécaux plus efficaces que par voie intraveineuse

Anesthésiques locaux et opioïdes; Peut être contrôlée par le patient

Continuer la posologie de base

Fournir les besoins de base par perfusion continue; Prévoir des besoins accrus de $30-50 \%$

Acétaminophène, Antiinflammatoires non stéroïdiens Kétamine, clonidine, gabapentine classes de médicaments pendant un épisode douloureux aigu médical ou chirurgical. Il faut donc, en préopératoire, savoir identifier les patients qui consomment des opioïdes quelque soit la raison, ceux qui souffrent de douleurs chroniques, et les états psychologiques fréquemment associés, comme la dépression, l'anxiété et les troubles de personnalité. Le premier principe à respecter chez ces patients à haut risque sera de n'induire ni sevrage, ni $\mathrm{OIH}$ en période périopératoire.

L'approche doit être multidisciplinaire et les questions suivantes doivent être abordées dès la période préopératoire : quels opioïdes seront utilisés (type, fréquence, doses); quelles seront les options postopératoires analgésiques (anesthésie locorégionale, analgésie multimodale); et quel sera le suivi et la prise en charge du patient vis-à-vis de sa douleur, de ses troubles du comportement (principalement anxio-dépressifs), ou des signes de sevrage en opioïdes s'il devait y avoir un sous-dosage momentané en analgésiques opioïdes. Il semble que parmi les facteurs psychologiques qui affectent le devenir de tels patients après chirurgie, la dépression et l'anxiété avant chirurgie induisent plus de risque de développer un haut niveau de douleur postopératoire, une plus lente réhabilitation et plus de plaintes postopératoires.

Certains modèles d'auto-prise en charge de la douleur ont été récemment proposés pour aider ces patients à ne plus être simplement passifs, mais plutôt actifs vis-à-vis leur douleur. ${ }^{15} \mathrm{Ce}$ genre d'approche active permet un partage des décisions entre le patient et l'équipe soignante afin d'optimiser le niveau d'investissement du patient dans son traitement et d'améliorer la prise en charge de sa douleur. Avant toute anesthésie, il faudra donc évaluer la consommation totale quotidienne du patient sous traitement opiö̈de au long cours. Des tables de correspondances sont à disposition et doivent être utilisées pour connaître la valeur de base d'opioïdes consommés par le patient (Tableau 3). Le calcul doit tenir compte des éléments suivants: voie d'administration; paramètres pharmacocinétiques; et absorption (par exemple : la morphine per os est moins rapidement absorbée que la méthadone ou l'oxycodone à libération prolongée). Le fentanyl transcutané ou son équivalent doit habituellement être continué en postopératoire

Tableau 3 Doses d'analgésiques opioïdes équipotentes (mg), d'après ${ }^{10}$

\begin{tabular}{lcc}
\hline Médicament & Dose orale & Dose parentérale \\
\hline Morphine & 15 & 5 \\
Hydromorphone & 4 & 1 \\
Fentanyl & - & 0,1 \\
Méthadone (aigu) & 0,8 & 1 \\
Oxycodone & 10 & - \\
\hline
\end{tabular}


comme analgésie dite basale. Cependant, l'absorption du fentanyl peut être modifiée et aléatoire en fonction de la chirurgie, de la quantité de liquides administrés en peropératoire et de la température cutanée de fin d'intervention. Il est donc préférable dans la plupart de ces cas d'enlever ces timbres et de substituer une dose équipotente de morphine. En effet, certaines études ont rapporté les risques induits par l'hypothermie $^{16}$ ou le réchauffement ${ }^{17}$ sur la cinétique d'absorption du fentanyl.

La dose habituelle d'opioïdes ou son équivalent doit être donnée le matin de la chirurgie ou à l'induction. Si le patient se présente avec un système implanté d'administration d'opioïdes intrathécal ou péridural, on doit continuer la même posologie durant toute la chirurgie. Depuis de nombreuses années, le principe de rotation préopératoire des opioïdes a été proposé pour limiter le risque de sevrage et l'OIH, et ainsi diminuer les doses d'opiö̈des. Toutefois, il faut impérativement éviter d'utiliser des agonistes-antagonistes (nalbuphine, buprénorphine, pentazocine...), qui peuvent induire un sevrage brutal ou une OIH. La rotation vers un autre opioïde agoniste $\mu$ permet le plus souvent une réduction des doses totales équivalentes d'opioïdes à cause d'une tolérance croisée incomplète entre opiö̈des. Cependant, cette rotation préopératoire semble difficile à réaliser en pratique puisqu'il faut titrer très progressivement le passage d'un opioïde à l'autre. ${ }^{18}$ De plus, on ne sait pas si cette rotation pourrait avoir un impact en termes de douleur postopératoire, de tolérance et d'OIH. Enfin, certains auteurs ont proposé une dose test de fentanyl ${ }^{19}$ afin d'estimer en préopératoire la réactivité de ces patients aux opioïdes utilisés en peropératoire. Ce test reste difficile d'application en pratique clinique.

L'analgésie multimodale, comportant l'administration d'acétaminophène et d'anti-inflammatoires sélectifs de la COX-2 ou classiques per os 1 ou $2 \mathrm{~h}$ avant chirurgie, est recommandée. La plupart des médicaments non opioïdes n'ont pas été testés spécifiquement chez des patients avec douleurs chroniques, mais ont été associés à une diminution de la consommation de morphine en postopératoire chez des sujets non dépendants aux opioïdes. Enfin, de nouvelles thérapies visant à limiter la sensibilisation postopératoire à la douleur et la chronicisation de cette douleur pourrait être utiles en prémédication. Ainsi, la gabapentine 600 à $1200 \mathrm{mg}$ et la prégabaline ont été proposées comme adjuvants à l'analgésie périopératoire. ${ }^{20} \mathrm{Si}$ elles n'ont pas non plus été testées chez le consommateur d'opioïdes chronique, elles pourraient cependant présenter un intérêt certain chez ces patients. L'anesthésie et analgésie locorégionale permettra de limiter la douleur au site chirurgical mais ne limitera en aucun cas les symptômes d'un sevrage aigu en opioïdes et ses conséquences systémiques.

\section{Période peropératoire}

Si certains auteurs ont mis en évidence une tolérance aiguë à certains opioïdes que l'on utilise en période peropératoire chez l'homme ou l'animal, ${ }^{11}$ rien n'a encore une fois été rapporté chez les patients consommateurs chroniques d'opioïdes. De la même façon, si l'OIH induite par les fortes doses d'opioïdes peropératoires a été rapportée avec la majorité des opioïdes utilisés en pratique clinique (fentanyl, rémifentanil, sufentanil, alfentanil), ${ }^{10,14}$ aucun élément ne permet de dire chez le sujet traité de façon chronique par opioïdes quel serait l'opioïde de choix à utiliser en peropératoire et quel degré de tolérance existerait en peropératoire. Le choix de l'opioïde reste donc à la discrétion de l'anesthésiste en charge du patient, et les doses sont à adapter selon la manière habituelle. L'anesthésie locorégionale devra être privilégiée pour limiter les doses peropératoires d'opioïdes, soit par la mise en place de cathéters, soit par des infiltrations à durée prolongée. ${ }^{21}$ Cependant il ne faut pas oublier que cette analgésie ne sera que localisée à la zone chirurgicale et ne pourra en aucun cas limiter les effets systémiques d'un sevrage en opioïdes qu'il faudra donc prévenir.

La kétamine, antagoniste des récepteurs $n$-méthyl-D-aspartate (NMDA), a montré son efficacité à réduire hyperalgésies et consommation postopératoire de morphine chez des animaux ou patients non tolérants. ${ }^{12}$ Administrée en périopératoire, elle permet la réduction des hyperalgésies péricicatricielles. ${ }^{10}$ Plusieurs méta-analyses récentes rapportent que l'effet bénéfique de la kétamine sur l'intensité des douleurs postopératoires et la consommation d'analgésiques dépasse les 5 demi-vies d'élimination du produit. $^{22,23}$ Les doses recommandées de kétamine sont présentées dans le Tableau 4. Malgré l'absence de données chez le patient tolérant, il semble logique de l'offrir comme solution thérapeutique adjuvante afin de diminuer les quantités d'opioïdes utilisés en périopératoire et d'essayer de bloquer l'OIH et la tolérance postopératoire. ${ }^{7}$ Une étude récente s'est penchée sur des patients tolérants en salle de réveil, et a révélé l'intérêt d'un simple bolus postopératoire
Tableau 4 Exemple de posologie de kétamine

\begin{tabular}{llll}
\hline Type de chirurgie & Induction & Entretien \\
\cline { 3 - 4 } & & Perfusion & Bolus \\
\hline Très douloureuse & $0,5 \mathrm{mg} \cdot \mathrm{kg}^{-1}$ & $0,5 \mathrm{mg} \cdot \mathrm{kg}^{-1} \cdot \mathrm{h}^{-1}$ & $0,25 \mathrm{mg} \cdot \mathrm{kg}^{-1}$ aux 30 min \\
Modérément douloureuse & $0,25 \mathrm{mg} \cdot \mathrm{kg}^{-1}$ & $0,25 \mathrm{mg} \cdot \mathrm{kg}^{-1} \cdot \mathrm{h}^{-1}$ & $0,125 \mathrm{mg} \cdot \mathrm{kg}^{-1}$ aux 30 min \\
\hline
\end{tabular}


de kétamine pour limiter la tolérance aiguë à la morphine en postopératoire. ${ }^{24}$ Le dextrométorphan présente les mêmes propriétés que la kétamine mais a été beaucoup moins étudié. Outre la kétamine, la clonidine et la dexmedétomidine ont fait l'objet d'études. La clonidine réduit la zone d'hyperalgésie secondaire et la consommation de morphine en postopératoire. ${ }^{12}$ Toutefois, elle présente des effets indésirables hémodynamiques marqués lors d'injections intrathécales. La dexmédétomidine intraveineuse semble limiter les symptômes du syndrome de sevrage chez ces patients particuliers consommateurs chroniques d'opioïdes. $^{25}$

Le type de chirurgie doit être pris en compte : quelques auteurs suggèrent qu'après chirurgie associée à une diminution substantielle des douleurs, les doses d'opioïdes proposées au patient doivent être réduites, car il y a un risque de dépression respiratoire. ${ }^{3,9}$ Certains auteurs proposent de titrer les opioïdes pour permettre une reprise de la respiration spontanée à une fréquence de $12-14 \mathrm{~min}^{-1}$. Finalement, il semble que ces patients consommateurs chroniques d'opioïdes doivent être considérés comme à plus haut risque d'inhalation pulmonaire du fait du retard de vidange gastrique qui les touche. L'anesthésie doit donc être préparée et conduite de telle sorte à limiter ce risque.

\section{Période postopératoire}

Une combinaison intrathécale ou péridurale de faibles doses d'opioïdes avec les anesthésiques locaux est couramment utilisée dans la plupart des institutions. En effet, il se peut qu'il y ait une régulation à la baisse (« down-regulation ») des récepteurs centraux aux opioïdes lors d'utilisation intrathécale ou péridurale d'opioïdes alors que l'action analgésique de l'anesthésique local n'est pas entachée par cette tolérance aux opiö̈des. L'analgésie locorégionale médullaire diminue l'allodynie péricicatricielle autour de l'incision chirurgicale et permet une réduction des douleurs postopératoires chroniques.

Un exemple de ce type d'analgésie par voie péridurale ferait appel à la bupivacaïne à faible concentration $\left(0,625 \mathrm{mg} \cdot \mathrm{mL}^{-1}\right.$ ou $\left.0,0625 \%\right)$ plus souvent qu'à la ropivacaïne, principalement pour des raisons de coût. L'adjonction d'opioïdes (par exemple fentanyl $2 \mu \mathrm{g} \cdot \mathrm{mL}^{-1}$ ou sufentanil $0,5-1,0 \mu \mathrm{g} \cdot \mathrm{mL}^{-1}$ ) à la solution d'anesthésiques locaux est le plus souvent proposée. Le débit d'infusion péridurale continue peut varier de 5 à $10 \mathrm{~mL} \cdot \mathrm{h}^{-1}$ et des bolus de 2 à $5 \mathrm{~mL}$ contrôlés par le patient seront accordés avec une période réfractaire de 8 à $10 \mathrm{~min}^{3}$

Si les patients ont une pompe d'opioïdes implantée en pré- et peropératoire, il faut maintenir la même posologie pour prodiguer une «analgésie dite basale » au patient. Pour les opioïdes, la voie neuraxiale semble être plus efficace que la voie intraveineuse. Il faut aussi adapter les doses aux doses préopératoires en terme d'équipotence. ${ }^{9}$ Cependant les risques d'OIH décrits ci-dessus existent aussi bien lors d'administration intraveineuse qu'intrathécale. ${ }^{26}$

Si le patient ne bénéficie pas d'anesthésie locorégionale, il faudra envisager un relais par analgésie contrôlée par le patient (ACP) selon l'exemple suivant : si le patient prend l'équivalent de morphine $60 \mathrm{mg}$ per os par jour en préopératoire à, ceci correspond à $20 \mathrm{mg}$ de morphine intraveineuse par jour, soit une perfusion de base de morphine à $0,8 \mathrm{mg} \cdot \mathrm{h}^{-1}$, à laquelle on ajoute des bolus intermittents de 1-2 mg toutes les 6-10 min au besoin. Si le ratio doses demandées/doses reçues $>3$, il faudra augmenter les doses du débit continu de $20 \%$ et réévaluer le patient. Il faudra donc au moins assurer au patient un retour, du moins initialement, à ses doses préopératoires.

Bien souvent, il existe une augmentation des besoins pouvant aller de 30 à $50 \%$ par rapport aux équivalents préopératoires. Ceci n'est vrai que quand la chirurgie surajoute une composante douloureuse forte! Les patients pour qui la chirurgie elle-même permet une réduction des douleurs préopératoires auront des besoins réduits par rapport à la période préopératoire et nécessiteront moins d'opioïdes.

L'ACP de morphine a pour avantage chez ces patients de permettre un usage facile et sans délai, une concentration sérique stable et un soulagement avec une plus faible consommation totale, d'éviter les confrontations patient/ personnel soignant, l'anxiété et les épisodes aigus de sevrage. Mais parfois l'ajustement est difficile au départ et il existe un risque de comportement de pseudo-addiction. C'est pourquoi l'ACP de morphine était initialement controversée chez ces patients, mais est maintenant bien acceptée. $^{27}$ De plus, il faut considérer l'ajout de kétamine, de clonidine, d'acétaminophène, d'anti-inflammatoires non stéroïdiens, de gabapentine et/ou d'analgésie locorégionale.

\section{Cas particulier du toxicomane dépendant des opioïdes}

L'héroïne reste encore le produit de consommation principal des toxicomanes, bien que la consommation de cocaïne soit en augmentation constante. ${ }^{3}$ Aujourd'hui, environ un toxicomane sur trois s'injecte de l'héroïne, la majorité préférant la fumer ou bénéficier d'une administration intranasale. De plus, les dérivés de la morphine tels que l'oxycodone, l'hydromorphone et la méthadone ont maintenant fait l'objet d'un intérêt particulier. Par exemple, l'oxycodone en comprimé à libération prolongée peut être écrasée, mise sous forme de poudre puis réinjectée par voie intraveineuse ou «sniffée ». La méthadone sous forme de comprimés est également visée. Par ailleurs, il existe très souvent une polytoxicomanie avec d'autres produits dont la consommation augmente proportionnellement à celle de 
l'héroïne. Ces patients peuvent présenter des atteintes d'organes, des maladies infectieuses comme le VIH, la tuberculose, une hépatite, sans compter des problèmes d'ordre psychologique. Le développement d'une tolérance, d'une dépendance et l'apparition d'un syndrome de manque à l'arrêt de la prise de drogue compliquent le tableau.

Pour le toxicomane, il existe également la possibilité d'une substitution institutionnelle par la méthadone dans des centres spécialisés. ${ }^{28}$ Comme les autres patients sous traitement opioïde continu, ces toxicomanes sous héroïne ou méthadone présentent un état d'hyperalgésie. Ces patients se présentent au bloc opératoire pour une chirurgie liée à leur état (drainage d'abcès, remplacement valvulaire par exemple) ou en raison d'une pathologie courante (appendicectomie, ostéosynthèse d'une fracture, etc.). Les patients toxicomanes doivent recevoir une dose de base d'un opioïde en fonction de la dernière administration de l'opioïde utilisé et, pour l'héroïne, en fonction de la pureté du produit. Pour la morphine et l'héroïne, le syndrome de manque peut débuter 6 à 18 heures après la dernière prise, tandis que pour la méthadone il faut compter entre 24 et 48 heures. ${ }^{3}$ À noter qu'un ancien toxicomane est susceptible de retrouver une dépendance suite à l'utilisation de morphiniques en période périopératoire.

Dans tous les cas, il est impératif de rassurer le patient et de lui expliquer comment sa douleur sera prise en charge dans la période périopératoire. À cette fin, un véritable contrat de soins précis entre l'équipe soignante et le patient toxicomane doit être envisagé afin d'acquérir sa confiance. Le message clair à l'équipe soignante consiste à ne pas restreindre le traitement opioïde chez ces patients mais au contraire de traiter agressivement toute douleur tout en étant conscient des différences pharmacologiques et psychologiques impliquées (patient «simulateur»). Il faut également se garder de tout jugement inapproprié quant au fait que le patient est toxicomane. De plus, la période périopératoire n'est pas la meilleure période pour effectuer une tentative de sevrage ou de réhabilitation chez ces patients. Ceci sera revu à distance de l'hospitalisation avec l'équipe d'addictologie. Finalement, la prise en charge périopératoire de la douleur chez le patient spécifiquement traité par méthadone a été revue récemment. ${ }^{28}$ Quand une technique d'anesthésie locorégionale peut être réalisée en fonction du type de chirurgie et des particularités du patient, celle-ci doit être privilégiée.

\section{Cas clinique}

Un homme de 28 ans se présente en salle d'urgence avec un abdomen aigu. Le diagnostic d'appendicite aiguë est posé et le chirurgien de garde vous contacte pour effectuer une appendicectomie. Celle-ci est prévue dans 2 heures. Le patient est souffrant ( 7 sur 10 sur une échelle verbale numérique) et demande à être soulagé. A l'interrogatoire le patient admet une toxicomanie à l'héroïne depuis plusieurs mois mais n'a jamais été suivi médicalement. Il est par ailleurs en «bonne santé » sans antécédents notoires ni allergies.

\section{Directives pour compléter le module DPC}

1. Lisez les références indiquées en gras.

2. Consultez le site Internet du Journal canadien d'anesthésie (http://www.springer.com/medicine/anesthesio logy/>journal/12630), cliquez sur «DPC en ligne », et choisissez le module actuel (Prise en charge de la douleur chez le patient sous opioïdes).

3. Répondez aux questions à choix de réponses concernant le cas clinique.

4. Après avoir saisi toutes vos réponses, vous aurez accès aux explications d'experts pour tous les choix possibles.

5. Les participants peuvent réclamer un maximum de quatre heures de DPC pour un total de huit crédits sous la Section 3 du programme de DPC du Collège royal des médecins et chirurgiens du Canada.

Sponsoring Dr. Pierre Beaulieu is a clinician researcher of the Fonds de la Recherche en Santé du Québec (FRSQ).

Conflicts of interest None declared.

\section{References}

1. Hadi I, Morley-Forster PK, Dain S, Horrill K, Moulin DE. Brief review: perioperative management of the patient with chronic non-cancer pain. Can J Anesth 2006; 53: 1190-9.

2. Mehta V, Langford RM. Acute pain management for opioid dependent patients. Anaesthesia 2006; 61: 269-76.

3. Mitra S, Sinatra RS. Perioperative management of acute pain in the opioid-dependent patient. Anesthesiology 2004; 101: 212-27.

4. Breivik $H$, Collett B, Ventafridda V, Cohen $R$, Gallacher D. Survey of chronic pain in Europe: prevalence, impact on daily life, and treatment. Eur J Pain 2006; 10: 287-333.

5. Moulin DE, Clark AJ, Speechley M, Morley-Forster PK. Chronic pain in Canada-prevalence, treatment, impact and the role of opioid analgesia. Pain Res Manag 2002; 7: 179-84.

6. Moulin DE, Clark AJ, Gilron I, et al. Pharmacological management of chronic neuropathic pain-consensus statement and guidelines from the Canadian Pain Society. Pain Res Manag 2007; 12: 13-21.

7. Carroll IR, Angst MS, Clark JD. Management of perioperative pain in patients chronically consuming opioids. Reg Anesth Pain Med 2004; 29: 576-91.

8. de Leon-Casasola OA, Myers DP, Donaparthi $S$, et al. A comparison of postoperative epidural analgesia between patients with chronic cancer taking high doses of oral opioids versus opioidnaive patients. Anesth Analg 1993; 76: 302-7. 
9. Rapp SE, Ready LB, Nessly ML. Acute pain management in patients with prior opioid consumption: a case-controlled retrospective review. Pain 1995; 61: 195-201.

10. Joly V, Richebe P, Guignard B, et al. Remifentanil-induced postoperative hyperalgesia and its prevention with small-dose ketamine. Anesthesiology 2005; 103: 147-55.

11. Kissin I, Bright CA, Bradley EL Jr. Acute tolerance to continuously infused alfentanil: the role of cholecystokinin and $\mathrm{N}$ methyl-D-aspartate-nitric oxide systems. Anesth Analg 2000; 91 : 110-6.

12. Richebe $P$, Rivat $C$, Laulin JP, Maurette P, Simonnet $G$. Ketamine improves the management of exaggerated postoperative pain observed in perioperative fentanyl-treated rats. Anesthesiology 2005; 102: 421-8.

13. Angst $M S$, Clark JD. Opioid-induced hyperalgesia: a qualitative systematic review. Anesthesiology 2006; 104: 570-87.

14. Chia YY, Liu K, Wang JJ, Kио MC, Ho ST. Intraoperative high dose fentanyl induces postoperative fentanyl tolerance. Can J Anesth 1999; 46: 872-7.

15. Jensen MP, Nielson WR, Kerns RD. Toward the development of a motivational model of pain self-management. J Pain 2003; 4: 477-92.

16. Rose DK, Cohen MM, Yee DA. Changing the practice of pain management. Anesth Analg 1997; 84: 764-72.

17. Frolich MA, Giannotti A, Modell JH. Opioid overdose in a patient using a fentanyl patch during treatment with a warming blanket. Anesth Analg 2001; 93: 647-8.

18. Inturrisi CE. Clinical pharmacology of opioids for pain. Clin $\mathbf{J}$ Pain 2002; 18: S3-13.

19. Davis JJ, Swenson JD, Hall RH, et al. Preoperative "fentanyl challenge" as a tool to estimate postoperative opioid dosing in chronic opioid-consuming patients. Anesth Analg 2005; 101: 389-95.
20. Tiippana EM, Hamunen K, Kontinen VK, Kalso E. Do surgical patients benefit from perioperative gabapentin/pregabalin? A systematic review of efficacy and safety. Anesth Analg 2007; 104: 1545-56.

21. Beaussier M, El'Ayoubi H, Schiffer E, et al. Continuous preperitoneal infusion of ropivacaine provides effective analgesia and accelerates recovery after colorectal surgery: a randomized, double-blind, placebo-controlled study. Anesthesiology 2007; 107: 461-8.

22. Bell RF, Dahl JB, Moore RA, Kalso E. Peri-operative ketamine for acute post-operative pain: a quantitative and qualitative systematic review (Cochrane review). Acta Anaesthesiol Scand 2005; 49: 1405-28.

23. Elia $N$, Tramer MR. Ketamine and postoperative pain-a quantitative systematic review of randomised trials. Pain 2005; 113: 61-70.

24. Weinbroum AA. A single small dose of postoperative ketamine provides rapid and sustained improvement in morphine analgesia in the presence of morphine-resistant pain. Anesth Analg 2003; 96: 789-95.

25. Arain SR, Ruehlow RM, Uhrich TD, Ebert TJ. The efficacy of dexmedetomidine versus morphine for postoperative analgesia after major inpatient surgery. Anesth Analg 2004; 98: 153-8.

26. Van Elstraete AC, Sitbon P, Trabold F, Mazoit JX, Benhamou D. A single dose of intrathecal morphine in rats induces long-lasting hyperalgesia: the protective effect of prior administration of ketamine. Anesth Analg 2005; 101: 1750-6.

27. Macintyre PE. Safety and efficacy of patient-controlled analgesia. Br J Anaesth 2001; 87: 36-46.

28. Peng PW, Tumber PS, Gourlay D. Review article: perioperative pain management of patients on methadone therapy. Can J Anesth 2005; 52: 513-23. 